\title{
A SOCIAL ACCOUNTING MATRIX FOR KYRGYZSTAN FOR 2010
}

\author{
Kamalbek KARIMŞAKOV ${ }^{1}$, Metin KARADAG ${ }^{2}$
}

\begin{abstract}
The main aim of this paper is to construct a latest Social Accounting Matrix (SAM) for Kyrgyzstan economy for the year 2010. The constructed SAM shows the interaction between production, income, consumption and capital accumulation in the economy. The dataset for the SAM is mainly based on the input-output table and national account system data for the country. The SAM can be used to provide an analysis of the interrelationship between the production structure of the economy and the distribution of incomes and expenditures of different household groups in the country. In addition, it can be used as a data base for the CGE modelling for the Kyrgyz economy for different policy simulations. The constructed SAM consists of 20 production sectors of the economy, two factors of production and ten categories of households. It also has the accounts for government and the rest of the World.
\end{abstract}

Keywords: Input-Output Table, Social Accounting Matrix, data for CGE modeling, Kyrgyz economy.

\section{Introduction}

A social accounting matrix (SAM) basically represents transactions in a complete economic system. In this context, SAM captures the transactions and transfers between all economic agents in an economy (Pyatt and Round, 1985; Reinert and RolandHolst, 1997). It is a square matrix whose corresponding columns and rows present the expenditure and receipt accounts of economic actors and all corresponding row and column totals are equal. SAM represents the whole economic system of a country and thus highlights the circular flow of payments and receipts among the different components of the system such as goods, activities, factors, institutions, and the "Rest of the World" (ROW), meaning, all actors outside the economic system being studied. In other words, a SAM is a simple and efficient way of representing the fundamental law of the economics that for every income there is a corresponding outlay or spending. It describes various channels through which production is linked with income distribution, consumption, savings, investment and external trade. Also, it provides a comprehensive and consistent description of the transactions taking place in an economy for a given year.
Therefore, we can use a SAM to analyse the relationship between production structures, income distribution and consumption profile of different household groups in an economy (Round, 2002). The social accounting matrix (SAM) has been extensively used as a tool for policy analysis in the last four decades by researchers (see for example, Pyatt and Round, 1985; King, 1985; Pyatt, 1991; De Santis and Orhan, 1997; Round, 2003; Deb Pal et al., 2012). In recent years, SAMs have been used as the database of Computable General Equilibrium Models by many researchers (see for example Karadag and Westaway, 1999; Yeldan, 1999; Akkemik, 2012;).

To the authors' best knowledge, there have been three previous attempts to construct a SAM for Kyrgyzstan. 2001 SAM for Kyrgyzstan constructed by the World Bank consists of 88 sectors of the economy, two factors of production and two type of households, namely rich and poor (World Bank, 2005, p.14). Although the production sector is highly disaggregated in this SAM, the household sector is not very detailed for analyzing income distribution purposes. Also another SAM constructed as a World Bank project, includes 52 sectors and two factors of 
production'. Household has been disaggregated into 20 groups (10 urban and 10 rural household groups). Moreover, Mogilevski and Omorova (2011) constructed a SAM for Kyrgyzstan for the year 2006. This SAM has 12 sectors, three labor types according to the education level and four capital types. Households have not been disaggregated and represented by single account. Additionally, three types of taxes are given: direct, import, and other indirect taxes.

Given these previous SAMs the main aim of this study is to construct a SAM for Kyrgyzstan economy for the year 2010 using the latest available data ${ }^{2}$. In construction of the SAM inter-industry balance for 2010 and national accounts data for 2010-2011 are used. Household is disaggregated by 10 decile groups. Therefore, the main feature of this SAM is the use of latest data and disaggregation of household by income groups, which was previously done only in 2003 SAM. This approach allows for income distribution analysis of economic policies within CGE modeling because the design of this SAM is conditioned by CGE modelling perspectives.
The rest of this paper is organised as the following. Section 2 gives basic information about Kyrgyz economy. Section 3 presents a basic structure of a SAM. Section 4 gives the information about data requirements and procedures in building the SAM for Kyrgyzstan. Section 5 gives the conclusion of the study.

\section{Brief Information about Kyrgyzstan Economy}

During the large-scale post-Soviet economic reforms in 1990s, Kyrgyzstan was considered as one of the most reformist economies. Comprehensive economic reform packages on price and trade liberalization and mass privatization found strong support from international financial organizations. However, economic growth during the post-reformist period in 2000s has been remaining unsustainable (see for instance, Pomfret, 2010). In particular, political events happened in 2005 and 2010 affected economic performance negatively of the country. The following table shows the main macroeconomic indicators for the Kyrgyz economy for the time period between 2002 and 2011.

Table 1: Macroeconomic indicators of Kyrgyzstan Economy (2002-2011)

\begin{tabular}{|c|c|c|c|c|c|c|c|c|c|c|}
\hline & 2002 & 2003 & 2004 & 2005 & 2006 & 2007 & 2008 & 2009 & 2010 & 2011 \\
\hline GDP growth (annual \%) & 0.0 & 7.0 & 7.0 & -0.2 & 3.1 & 8.5 & 8.4 & 2.9 & -0.5 & 6.0 \\
\hline $\begin{array}{l}\text { GDP percapita, PPP } \\
\text { (constant } 2005 \text { international \$) }\end{array}$ & 1557 & 1649 & 1744 & 1721 & 1756 & 1888 & 2027 & 2060 & 2026 & 2121 \\
\hline Agriculture, valueadded (\% of GDP) & 38 & 37 & 33 & 32 & 33 & 31 & 27 & 21 & 19 & 19 \\
\hline Industry, valueadded (\% of GDP) & 23 & 22 & 24 & 22 & 20 & 19 & 24 & 27 & 29 & 31 \\
\hline Services, etc.,valueadded (\% of GDP) & 39 & 41 & 43 & 46 & 47 & 50 & 49 & 52 & 51 & 51 \\
\hline Trade, valueadded (\% of GDP) & 14 & 16 & 19 & 20 & 22 & 21 & 21 & 19 & 18 & 19 \\
\hline Consumer Price Index $*$ & 2.1 & 3.1 & 4.1 & 4.3 & 5.6 & 10.2 & 24.5 & 6.8 & 8 & 16.6 \\
\hline Current account balance (\% of GDP) & -1.8 & -2.2 & 1.3 & -1.5 & -10.1 & -6.0 & -13.6 & -2.2 & -8.0 & -4.3 \\
\hline Government Budget Balance (\% of GDP) & & -0.9 & -0.5 & 0.2 & -0.2 & 0.1 & 0.8 & -1.5 & -4.9 & -4.7 \\
\hline GINI index & 0.42 & 0.41 & 0.42 & 0.433 & 0.45 & 0.42 & 0.363 & 0.37 & 0.371 & 0.382 \\
\hline Poverty & 54.8 & 49.9 & 45.9 & 43.1 & 39.9 & 35 & 31.7 & 31.7 & 33.7 & 36.8 \\
\hline Workers' remittancesreceived (\% of GDP) & 2.29 & 4.07 & 8.53 & 13.09 & 16.98 & 18.80 & 23.98 & 21.15 & 26.60 & 29.00 \\
\hline
\end{tabular}

Source: Living Standards in Kyrgyzstan 2006-2010; Living Standards in Kyrgyzstan 2007-2011; World Bank WDI;

Bulletin of the NBKR 2012, 2008.

* compared to the previous year

http://www.stat.kg/stat.files/din.files/prise/1080001\%20(КРПТУН).pdf

http://wWw.stat.kg/stat.files/din.files/prise/1080001\%20(КИПЦ).pdf

\footnotetext{
${ }^{1}$ Although, this SAM has not been published yet, we used the necessary data from this source with the permission of Miles Light. In this respect, the authors would like to thank Miles Light for providing this dataset for us.

2 The latest available Input-Output Table for Kyrgyzstan was for the year 2010 when this study carried out.
} 
As can be seen from the Table 1, although the share of agricultural sector in total GDP has decreased in recent years, still it has a relatively high share (19\% in 2011). On the other hand, the shares of services and industry sectors have increased in recent years. In spite of the fact that the poverty level has decreased substantially since 2002 , still its level is high - 36.8 per cent. Despite the fact that per capita income level increased since 2002, Kyrgyzstan remains as the low income level countries. Income distribution in last ten years performed slight improvement, but it does not represent considerable changes. The Gini Coefficient has got worse since 2008. These features and high dependence on imported goods cause sensitivity of Kyrgyzstan economy to external shocks. Moreover, the country has experienced twin deficits since 2009.

Weak economic conditions contributed to migration of labor force mainly to Russia. Nowadays, remittances sent by migrants outside of Kyrgyzstan are important income source of the economy. According to the World Bank (2012) Kyrgyzstan ranks $3^{\text {rd }}$ among the top 10 recipients of migrant remittances as a share of GDP in 2011. Such large amount of remittances inflow helps reduction in deficit of balance of payments and can be seen as one of the major factors in sustaining livelihood of most rural population.

\section{Basic Structure of a SAM}

A Social Accounting Matrix or SAM is an accounting framework which encapsulates structural interrelationships between the different sectors in an economy. Basically, it is a way of representing the fundamental law of the economics that for every income there is a corresponding outlay or expenditure in an efficient way. The most important things to be noted are that it is a square matrix and that all corresponding row and column totals are equal in constructing a SAM. As mentioned before the SAM accounts provide the basic data set for CGE modelling as well.

The following table presents an aggregated SAM for a national economy in a schematic form in which elements of the matrix are labelled according to the type of transaction they represent. 


\begin{tabular}{|c|c|c|c|c|c|c|c|c|c|}
\hline \multirow{8}{*}{ 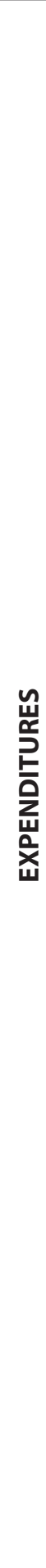 } & $\begin{array}{l}\overline{0} \\
\stackrel{0}{0}\end{array}$ & $\begin{array}{l}\frac{\tilde{c}}{\tilde{n}} \\
\frac{\tilde{n}}{\pi} \\
\stackrel{0}{0}\end{array}$ & 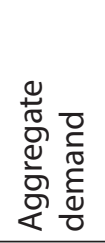 & 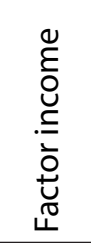 & 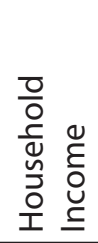 & 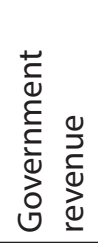 & 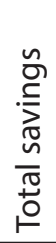 & 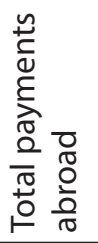 & \\
\hline & కై & 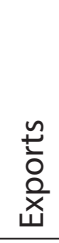 & & & 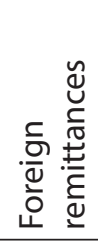 & 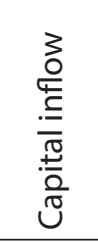 & 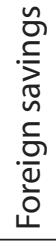 & & 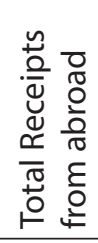 \\
\hline & 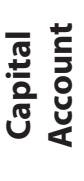 & & 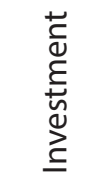 & & & & & & $\bar{r}$ \\
\hline & 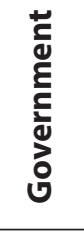 & & 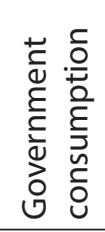 & & 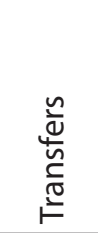 & & 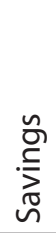 & & 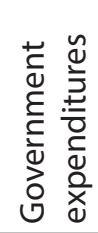 \\
\hline & 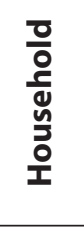 & & 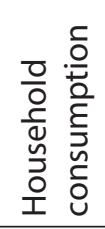 & & & 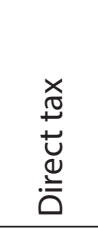 & 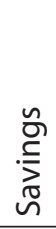 & & 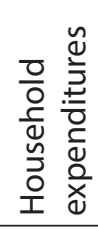 \\
\hline & 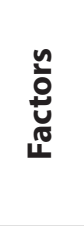 & & & & 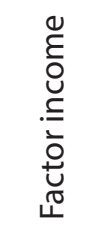 & & & & 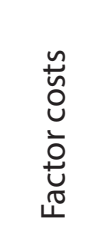 \\
\hline & 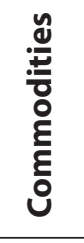 & 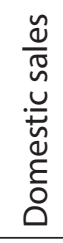 & & & & & & 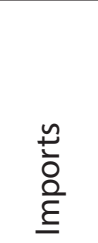 & 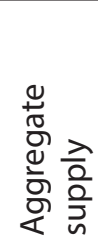 \\
\hline & 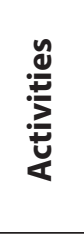 & & 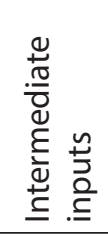 & 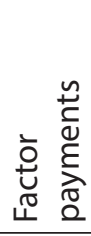 & & & & & 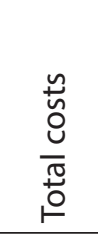 \\
\hline & & 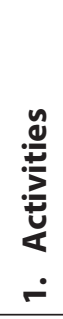 & 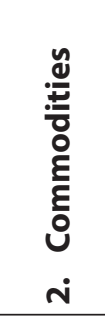 & 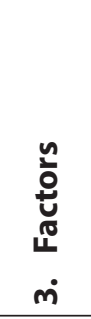 & 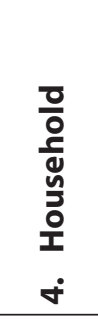 & 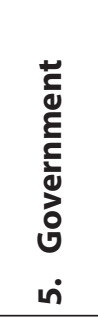 & 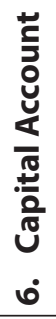 & $\begin{array}{l}3 \\
0 \\
x \\
\wedge\end{array}$ & $\begin{array}{l}\text { నే } \\
\stackrel{0}{\circ}\end{array}$ \\
\hline
\end{tabular}


As can be seen from Table 2, the rows and columns of this square matrix are given as identical labels. The basic principle of double-entry accounting requires that total revenue equals total expenditure for each account in the SAM. In other words, account's row and column totals must be equal. The basic structure in this table recognizes 7 types of account which can be grouped into three categories. First of all, the SAM contains the production accounts from 1 to 3 (a set of accounts for production activities, commodities and factors of production that represent total accounts for production within the economy). Secondly, the household account is given in account 4. Also, the SAM gives both the current and the capital accounts for institutions (numbered 5-6). Finally, the aggregated SAM in the table shows a distinction between the domestic economy (accounts 1 to 7) and the rest of the world or ROW for short (account 7). Thus, the SAM shows from where each account derives its receipts and how the income is distributed to the other accounts.

\section{Construction of the SAM for the Kyrgyz Economy}

The first stage in compiling the SAM is to construct an aggregated SAM using available published data related to production, consumption government budget, and rest of the world for the economy. The main statistical sources used to achieve this task are:

- Input-Output table for 2010 by National Statistical Committee of Kyrgyz Republic (NSCKR)

- NSCKR"National Accounts 2007-2011" report

- NSCKR "Living Standard of Population in Kyrgyz Republic2006-2010" report

- Bulletin of the National Bank of Kyrgyz Republic (NBKR) for 2012.

- Household Budget Survey 2003.

The SAM provides a framework for reconciling an input-output table, national income accounts and other necessary data for Kyrgyzstan. The most recently published input-output table belongs to 2010 and this provides the detailed information that forms the basis of especially the production accounts in the SAM. Thus this was the year chosen as the representative year. Using other data from other sources, this input-output data was extended to incorporate information on domestic household groups consistent with the production side accounts and also to explicitly incorporate an external sector balance condition which is not present in the inputoutput data. As the data required for the SAM is so comprehensive, the sources are necessarily divergent. Therefore, some adjustments need to be made to ensure that all parts of the data are consistent with each other. Since the input-output table forms the backbone in constructing the SAM, all data on industry are taken to be fixed while data on household incomes and expenditures are correspondingly adjusted by using the RAS method used by researchers (see, for example, De Santis and Orhan, 1997; Karadag and Westaway, 1999; Unlukaplan 2009). As one of the ultimate aims for constructing the SAM was general equilibrium tax policy analysis, it is necessary to incorporate substantially more detail on taxes than exists in either the input-output table or the income and expenditure accounts. In this context, we divide indirect taxes between indirect taxes on production and indirect taxes on consumption (such as VAT).

Table 3 shows an aggregated SAM for Kyrgyzstan for the year 2010. As can be seen from the table, the aggregated SAM consists of activities, commodities, factors, household, government, indirect taxes, capital account and rest of the world (ROW) accounts (8 accounts) $)^{3}$. Then, mainly the production and consumptions sectors are disaggregated for the aim of the study. In this context, activities and commodities are each disaggregated according to the 2010 input-output table classification, hence comprising 20 accounts in each case. Also, households are disaggregated according to their income size (10 classes). This disaggregation may allow modellers to analyse the effects of policy changes on income distribution and on welfare of households. Factors account includes labor and capital. Indirect taxes account includes indirect taxes on production, consumption and import duties. Moreover, the capital account includes private gross fixed capital formation, public gross fixed capital formation and changes in stocks. Thus, the disaggregated SAM contains 56 accounts in total.

${ }^{3}$ The disaggregated SAM is available from the authors if requested. 


\begin{tabular}{|c|c|c|c|c|c|c|c|c|c|c|}
\hline $\begin{array}{l}\overline{0} \\
\stackrel{0}{0}\end{array}$ & $\underset{\underset{N}{N}}{\underset{f}{N}}$ & 苜 & $\begin{array}{l}\text { N } \\
8 \\
8\end{array}$ & $\begin{array}{l}\text { Na } \\
\text { ลั }\end{array}$ & 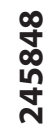 & $\begin{array}{l}\text { mo } \\
\text { ڤ్ } \\
\text { nn }\end{array}$ & $\begin{array}{l}n \\
0 \\
\infty \\
\stackrel{N}{N}\end{array}$ & 告 & ั̆ & \\
\hline రై & $\begin{array}{l}\stackrel{m}{m} \\
\stackrel{m}{\mathscr{L}} \\
\stackrel{m}{=}\end{array}$ & & & & 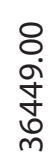 & $\begin{array}{l}\text { ○ } \\
\stackrel{\circ}{\circ} \\
\infty\end{array}$ & & 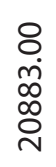 & & $\begin{array}{l}\text { જ̆ } \\
\text { જે }\end{array}$ \\
\hline 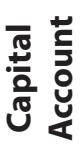 & & 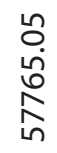 & & & & & & & & \begin{tabular}{l}
$n$ \\
\multirow{2}{*}{} \\
in
\end{tabular} \\
\hline 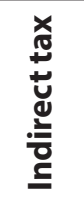 & & & & & & 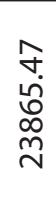 & & & & $\begin{array}{l}n \\
\stackrel{0}{0} \\
\stackrel{m}{N}\end{array}$ \\
\hline 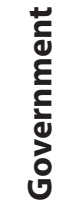 & & $\begin{array}{l}\bar{\sigma} \\
\bar{ָ} \\
\stackrel{\Gamma}{\sim}\end{array}$ & & & $\begin{array}{l}8 \\
\stackrel{\leftrightarrow}{n} \\
\stackrel{2}{N} \\
\stackrel{n}{n}\end{array}$ & & & 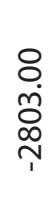 & & $\begin{array}{l}\text { ô } \\
\text { గ̂ } \\
\text { nิ }\end{array}$ \\
\hline 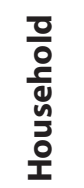 & & 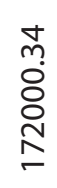 & & & & $\begin{array}{l}8 \\
\stackrel{\circ}{0} \\
\stackrel{N}{0} \\
\stackrel{N}{N}\end{array}$ & $\begin{array}{l}8 \\
\dot{ \pm} \\
\stackrel{n}{=}\end{array}$ & 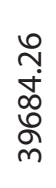 & & 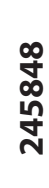 \\
\hline$\frac{\overline{0}}{\frac{ \pm}{2}}$ & & & & & $\begin{array}{l}\hat{\sigma} \\
\bar{\sigma} \\
\hat{\alpha} \\
\alpha\end{array}$ & & & & & No \\
\hline 흠 & & & & & 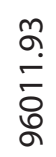 & & & & & ํㅜㅇ \\
\hline 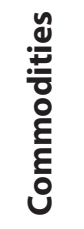 & 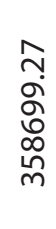 & & & & & & 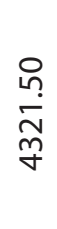 & & 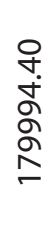 & \begin{tabular}{l}
$n$ \\
$\frac{n}{0}$ \\
\multirow{y}{*}{}
\end{tabular} \\
\hline 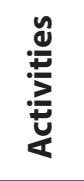 & & 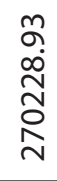 & $\frac{n}{\frac{n}{\sigma}}$ & $\begin{array}{l}\hat{o} \\
\bar{\sigma} \\
\text { స̆ }\end{array}$ & & & $\frac{\hat{\sigma}}{\stackrel{\sigma}{\alpha}}$ & & & $\underset{\underset{N}{N}}{\stackrel{m}{N}}$ \\
\hline & $\frac{\mathscr{U}}{\stackrel{\underline{z}}{Z}}$ & 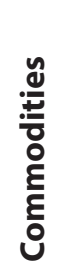 & $\begin{array}{l}\frac{1}{0} \\
\frac{0}{0}\end{array}$ & 原 & 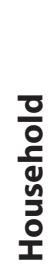 & 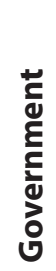 & 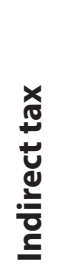 & 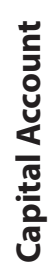 & రై & $\begin{array}{l}\bar{乛} \\
\text { 。 }\end{array}$ \\
\hline
\end{tabular}




\subsection{Production}

\section{Activities account}

Regarding the production account, activities and commodities are separated to allow greater flexibility in the determination of relative prices, as well as industrial structure. We need to separate the activity and commodity account, as activities are assumed to consist of producers who are behaviourally distinct in a modeling framework. In this context, activities account shows the value of output produced by sectors of economy and cost of production of each sector. As mentioned above SAM is largely based on the NSCKR Input-Output table, which classifies economy by 34 sectors. For the construction of SAM this I-O table has been aggregated into 20 sectors. The following table shows the sectoral aggregation regarding the production sector.

Table 4: The Sectoral Aggregation of Production

\begin{tabular}{|c|c|c|}
\hline $\begin{array}{l}\text { Sector } \\
\text { Code }\end{array}$ & Sectors in SAM & $\begin{array}{l}\text { Key to sectors in the } \\
\text { NSCKR I-O table }\end{array}$ \\
\hline AGR & Agriculture, forestry and fishing & $1-2$ \\
\hline MIN & Mining & $3-5$ \\
\hline FTB & Manufacture of food products, tobacco and beverages & 6 \\
\hline TEXL & $\begin{array}{l}\text { Manufacture of textile and textile products, leather and } \\
\text { leather products, footwear }\end{array}$ & 7 \\
\hline WP & $\begin{array}{l}\text { Manufacture of wood, paper products, publishing and } \\
\text { printing }\end{array}$ & $8-9$ \\
\hline PETC & $\begin{array}{l}\text { Manufacture of coke, refined petroleum, chemicals, and } \\
\text { non-metallic mineral products }\end{array}$ & $10-11$ \\
\hline MET & Manufacture of basic metals and fabricated metal products & $12-13$ \\
\hline MAC & Manufacture of machinery and equipment & $14-15$ \\
\hline ELT & Electricity generation and distribution services & 16 \\
\hline GAS & Gas fuel production and distribution & 17 \\
\hline WAT & Steam and hot water supply and distribution services & $18-19$ \\
\hline CON & Construction & 20 \\
\hline TRADE & Wholesale and retail trade & $21-22$ \\
\hline HOTR & Hotels and restaurants & 24 \\
\hline TRC & Transport and communication & $25-26$ \\
\hline FIN & Financial intermediation & 27 \\
\hline RER & Real estate, renting and business activities & 28 \\
\hline PUB & Public administration & 29 \\
\hline EDUH & Education and health & $30-31$ \\
\hline OS & Other services & $23,32-34$ \\
\hline
\end{tabular}

Column of the activities account refers to the costs of production, in other words expenditures made to intermediate inputs, factor payments and indirect taxes on production, while row shows supply of its products to domestic market and the rest of the world as exports. For the construction of expenditures 
and receipts of activities account data given in the I-O table have been used.

\section{Commodities account}

Separation of product account and commodities is a standard approach in construction of SAM (see Breisinger, et al. 2007; Karadag and Westaway, 1999; De Santis and Ozhan, 1997). This feature of SAM gives possibility to see the distribution of domestic production between domestic demand and total supply, and domestic demand by domestic production and import. Also, it provides with flexibility in output-consumption relation. As one commodity may be product of different activities, and activity may produce different commodities. In other words, there is no one-to-one relation between activities and commodities.

Commodities account also consists of 20 sectors listed in Table 2. Columns of the commodity account show payments to domestic activities, the rest of the world, and import duties. Rows of this account show sources of total demand: intermediate consumption by production account, consumption by households and government, and demand for investment purpose. Thus, column total gives aggregate supply, while demand total aggregate demand. Domestic sales obtained by subtracting exports from total output of production account.

\section{Factor account}

Factor account comprises labor and capital. As a standard approach "compensation of employees" in I-O table is used as labor income, while capital income is formed from "net operating surplus" and "use of fixed capital (capital depreciation)" rows.

According the National Accounts (2006-2010) report statistics dominant part of income in the economy is classified as gross mixed income. Mixed income is the income of unincorporated enterprises owned by households in which members of household can produce unpaid labor, including elements of remuneration for work (NSCKR, 2009, p. 12). In other words, it is difficult to distinguish income of labor force used for production and income of enterprise owner regarding mixed income. In the literature, some authors interpret mixed income as capital income (see for instance, Diwan, 2001), although, some others argue that interpretation of income from self-employment just completely as capital or labor income would be misleading (see for instance, Guscina, 2006; Gollin, 2002). In particular, Gollin (2002) states that under the conditions of large share of income of labor, which is selfemployed or employed in unincorporated sector, as in most developing economies, use of "employee compensation" may underestimate labor share in total factors income ${ }^{4}$.

Hence, mixed income has been distributed between labor and capital by taking the relative share in value added of each sector and the role of small and medium sized enterprises (SME) in these sectors into account.

\subsection{Household Sector}

Household account shows expenditure and income of household in an economy. Column refers to household expenditures on consumption, taxes and savings, while row shows income from labor, capital, government and transfers from abroad.

The single representative household in the aggregated SAM has been disaggregated into 10 income decile groups. The first decile group represents the households with the lowest income, while the tenth group represents the households with the highest income. We used, "Living Standards of Population in Kyrgyz Republic 2006-2010" for the disaggregation (National Statistical Committee of Kyrgyz Republic, 2011). We also used the data set provided by Light as mentioned above. Consumption of each household group is determined by using 2003 SAM provided by Light.

Regarding expenditures, households pay direct and indirect taxes (as consumption tax likeVAT) to the government. Indirect tax payment of all household decile groups have been estimated at the ratio of taxes on goods to household consumption calculated from I-O table. Shares of each household group in direct taxes and savings have been approximated using the data of NSCKR (2011). In the same vein, NSCKR (2011) gives income structure of households in per cent for ten decile groups. Sources of income have been aggregated as labor, capital, government and remittances from abroad.

\footnotetext{
${ }^{4}$ Stating this issue Gollin (2002) suggests adjustments for correction using Operating Surplus of Private Unincorporate Enterprises data (OSPUE). His approach was applied by Bernanke and Gurkaynak (2001) for labor share estimation for more than 50 countries, where Kyrgyzstan is not included.
} 


\subsection{Government}

Government account represents expenditures on column and revenues of government on row. Government makes payments to goods and services, social transfer to households and saves the rest. Government receives income from direct taxes, indirect taxes on production and on household final consumption and capital inflows from the rest of the world.

Government consumption data have been obtained from the I-O table, while values of social transfer, savings and capital inflow from abroad have been calculated from the government finance statistics of the NSCKR and NBKR data for 2010. Data on direct taxes and indirect taxes are as explained in activities, commodities and household accounts.

\section{Indirect taxes account}

Indirect taxes account includes taxes on activities, import duties and taxes on household consumption. Data on indirect taxes on activities obtained from the I-O table as net values by subtracting subsidies from taxes. Import duties and taxes on household consumption are described in commodities and household accounts correspondingly.

\section{Capital account}

Capital account shows investment by sectors of economy on column and savings by household, government and savings from the rest of the world on row. Data on investment by sectors of economy is the sum of "gross fixed capital accumulation" and "changes in inventories" obtained from the I-O table. Household and government savings and savings flow from abroad estimations are based on National
Account Systems, Government Finance, and Balance of Payments data for 2010.

\subsection{Rest of the World}

Rest of the world account indicates relations of the economy with the rest of the world. This account expenditures column shows export of economy, remittances inflow to households, capital inflow to government and capital investment as foreign savings, while receives income as import of economy from the rest of the world. Export and import cells of the SAM are based on I-O table data, while remittances and capital inflows to government and private sector are assessed on macroeconomic statistical data of the NSCKR and NBKR.

\section{Conclusion}

This SAM constructed with latest available data may serve as one of the tools in designing better formulated economic policies. In particular, inclusion of separate indirect taxes account and disaggregation of household by income level groups makes it possible to evaluate different possible scenarios by taking taxation and income distributional aspect of economic policy into account.

Social accounting matrix constructed in this study can be used as the database for CGE modeling that makes it applicable to wide range of policy analysis. Detailed description of an economy in terms of the production and consumption across sectors of economy and household groups, government expenditure and taxation allows for analyses of economic policy consequences on production and income distribution.

\section{References}

Akkemik, K. A. (2012) "Assessing the Importance of International Tourism for the Turkish Economy: A Social Accounting Matrix Analysis". Tourism Management, 33 (4), 790-801

Bernanke, B. and Gurkaynak, R. (2001) "Is Growth Exogenous? Taking Mankiw, Romer, and Weil Seriously".NBER Working Paper 8365

Breisinger, C., Thurlow, J., and Duncan, M. (2007) "A 2005 Social Accounting Matrix (SAM) For Ghana" Washington, D.C.: Ghana Statistical Services (GSS); International Food Policy Research Institute (IFPRI)
De Santis R. A. and H. Gazi Ozhan (1997) "Social Accounting Matrix for Turkey 1990".Economic Systems Research, 9(3): 281-285.

Deb Pal, B. Pohit, S.and Roy, J. (2012)"Social Accounting Matrix for India".Economic Systems Research, 24 (1): 77-99.

Diwan, I.(2001) “Debt as Sweat: Labor, financial crises, and the globalization of capital".Washington D.C: World Bank.

Gollin, D. (2002)"Getting income shares right".Journal of Political Economy, 110(2): 458-474. 
Guscina, A. (2006) "Effects of Globalization on Labor's Share in National Income" International Monetary Fund.

Karadag, M. andWestaway, T. (1999)“A SAM-based Computable General Equilibrium Model of the Turkish Economy". Loughborough University Economic Research Paper, 99 (18).

King, B. B. (1985). "What is a SAM?". In: Pyatt, G. andRound, J. I. Social Accounting Matrices: A Basis for Planning. Washington, DC: World Bank.

Mogilevsky, R. and Omorova, A.(2011)“Country Study: Assessing Development Strategies to Achieve the MDGs in the Kyrgyz Republic" United Nations Department for Social and Economic Affairs, March. (2006 SAM available at http://www.un.org/en/ development/desa/policy/capacity/output_sam. shtml. Accessed 1 November 2012)

National Bank of Kyrgyz Republic (2013) "Bulletin of the National Bank of Kyrgyz Republic for 2012" Bishkek. (in Russian)

National Statistical Committee of Kyrgyz Republic(2009) "Methodological Guide of InputOutput Tables".(in Russian) Available at:http:// www.stat.kg/stat.files/metod/CHC/Методика\%20 расчета\%20таблиц \%203атраты-Выпуск/ методика\%20МОБ.doc (Accessed 3 March 2013)

National Statistical Committee of Kyrgyz Republic (2011) "Living Standards of Population in Kyrgyz Republic 2006-2010". Bishkek (in Russian)

National Statistical Committee of Kyrgyz Republic (2012) "Kyrgyz Republic National Accounts 20062010" (in Russian)

National Statistical Committee of Kyrgyz Republic (2013) "Kyrgyz Republic National Accounts 20072011" (in Russian)

National Statistical Committee of Kyrgyz Republic, AppendixofInter-IndustryBalancefor2010.(inRussian)
Available at:http://stat.kg/index.php?option=com _ content\&task=view\&id=25\&ltemid=101

National Statistical Committee of Kyrgyz Republic, Household Budget Survey 2003

Pomfret, R. (2010) "Central Asia after Two Decades of Independence", UNU-WIDER WorkingPaper No. 2010/53.

Pyatt, G. (1991)“SAMs, The SNA and National Accounting Capabilities". Review of Income and Wealth, 37 (2): 177-198.

Pyatt, G.,andRound, J. (1985)“Social Accounting Matrices: A Basis for Planning". Washington D.C: World Bank.

Reinert, K. A. and Roland-Holst, D. W. (1997). "Social Accounting Matrices". In: Francois, J.F. and Reinhart, K.A,Applied Methods for Trade Policy Analysis. Cambridge, United Kingdom: Cambridge University Press.

Round, J. I. (2003a) "Constructing SAMs for Development Policy Analysis: Lessons Learnedand Challenges Ahead". Economic Systems Research, 15 (2), 161-183.

Unlukaplan, I. (2009) "A Social Accounting Matrix for the Turkish Economy" International Journal of Social Sciences and Humanity Studies, 1 (1), 17-26.

World Bank (2005)"Enhancing the Prospects for Growth and Trade of the Kyrgyz Republic". A World Bank Country Study, 34040.Washington D.C

World Bank (2012) "Migration and Development Brief 19". Available at: http://siteresources.worldbank.org/ INTPROSPECTS/Resources/334934-1288990760745/ MigrationDevelopmentBrief19.pdf (Accessed 18 November 2012)

World Bank, World Development Indicators.

Yeldan, E. (1998) "Financial Liberalization and Fiscal Repression in Turkey: Policy Analysis in a CGE Model with Financial Markets".Journal of Policy Modeling, 79:79-117. 